\title{
The Relationship between the Corporate Governance and the Stock Institutional Ownership with the Dividend- a Case Study of Tehran
}

\author{
Ramtin Safabakhsh Ghasemi ${ }^{1}$, Hassan madrakian ${ }^{2}$ Farshad Sameni Keivani ${ }^{3,4}$ \\ ${ }^{I}$ Department of Management, Qazvin Branch, Islamic Azad University, Qazvin, Iran \\ ${ }^{2}$ Assistant Professor, Department of Management, Qazvin Branch, Islamic Azad University, Qazvin, Iran \\ ${ }^{3}$ School of Social Sciences, Universiti Sains Malaysia, 11800 USM, Pulau Penang, Malaysia \\ ${ }^{4}$ Department of Accounting, Roudsar and Amlash Branch, Islamic Azad University, Roudsar, Iran
}

\begin{abstract}
This study focuses on the relationship between the corporate governance and the institutional stock ownership with the divided in Tehran stock exchange, which the corporate governance consist of variables such as: the board size, the board independence and the duality. The study uses the descriptive and analytical method based on a combined data analysis. It is applied the data of 81 accepted companies at Tehran Stock Exchange as a sample covering data from 2005 to 2011. Multi variables regression model is used to analysis the data. The results indicate the meaningful relationship between the corporate governance variable and the dividend. In other words, the companies with the lower rate of the corporate governance pay more dividends to the shareholders. In addition, there is not meaningful relationship between the institutional stock ownership and the dividend variables because the most of Iranian companies ownership structure owned by government institution. The results of this paper will be useful who want to involve in the capital market based on the company dividend decision makers the stock market in Iran.
\end{abstract}

Keywords: Corporate governance, Dividend policy, Institutional Stock ownership, Board Combination

\section{Introduction}

One of the important issues that always draw attention of economy, treasury and accounting is conflict of interests between managers and shareholders. After the industrial revolution along with the separation of ownership from management in companies, there is a possibility that managers could make decisions based on their interests and incompatible with interests of the shareholders. Generally, by the issues resulting from these contradictions and the way companies encounter these conflicts, in accounting terms, management is mentioned as "delegation theory" (ghaemi, Shariyari, 2009). In delegation relationship, the owners' objective is the maximization of the wealth and in order to achieve this goal they monitor agents and asset their performance. Corporate governance is a tool for developing balance between management and shareholders, and will cause a reduction in delegation problems. Another subject that may cause a conflict is that main shareholder and managers may use their control rights for individual gain, and may lead to the exploitation of other shareholders (Namazi, Kermani, 2008). These possibilities and unspecified effects of ownership on different aspects of company have made a variety of theories regarding behavior of institutional shareholders. Meanwhile, profit sharing policy is one of the cases affected by delegation conflicts. In general, there are two different opinions toward the relationship between the dividend and the delegation conflicts (Jahankhani, ghorbani, 2005). In the first view, the dividend is a solution for reducing the conflicts between managers and shareholders and in the second one it works as an alternative for delegation problems. However, findings of theoretical and empirical research indicate a significant relationship between the ownership structure and the Board Combination with the delegation costs (Nourvash et al., 2009).

\section{Literature review}

The delegation models indicate that the companies with higher corporate governance rate have higher dividend payouts and in companies with stronger corporate governance. There is a strong negative relation between growth and dividend (Mitton 2004). Two hypotheses, replacement and conclusion, showed different results pre and post financial crisis of Asia (sueeki 2006). The results before the crisis indicate an inverse relation between the corporate governance and the benefit sharing policy, and after that, this relationship undergoes positive changes.

Abdul salam, et al (2008), investigated the effect of board combination and ownership structure on dividend policies. In this regard, 50 Egyptian companies were investigated from 2003 to 2005 . The results emphasize that companies with more return on shareholders' equity and more institutional ownership, divide more profits. In 
addition, there is no significant relationship between the board composition and the dividend policy. Mac Cary, et al (2010) found that institutional inventers would like to involve in stock exchange activities.

The purpose of this study is to investigate the relationship between the corporate governance and the institutional ownership with dividend of accepted companies in Tehran stock exchange and therefore makes an effort to answer the following questions:

- Is there a significant relation between the dividend policy and the corporate governance indexes of accepted companies in Tehran stock exchange?

- Is there any significant relation between the dividend and the institutional ownership for accepted companies in Tehran stock exchange?

Hence, the main hypotheses of this survey are as follows:

$\mathrm{H}_{1}$ : There is a significant relationship between the dividend and the institutional stock ownership index in Tehran stock exchange.

$\mathrm{H}_{2}$ : There is a significant relationship between the dividend and the corporate governance index in Tehran stock exchange.

The secondary hypotheses of this study are as follows:

$\mathrm{H}_{2-1}$ : There is a significant relationship between dividend and board size index in Tehran stock exchange.

$\mathrm{H}_{2-2}$ : There is a significant relationship between dividend and board independency index in Tehran stock exchange.

$\mathrm{H}_{2-3}$ : There is a significant relationship between dividend and duality index in Tehran stock exchange.

\section{Materials and Methods}

The study is a descriptive research, since descriptive researches investigate phenomenon that occur naturally with no manipulation. Regarding path, it is a correlation research, since it investigates the relation between the variables. Correlation is one of the simplest and most common techniques, regarding the time of the research, it's linear, because it studies and collects data in a time intervals, and it's a field research in terms of collecting data. Since a field research studies variables in their natural environment and includes gathering data from variables (Iran nejad, Mahdi, research method in sociology, 2003). The location of the study is Tehran stock exchange. The statistical population includes all accepted companies in Tehran stock exchange from 2005 to 2011 (435 companies) except investing companies and financial intermediate companies, since they have different financial disclosure and ownership from independent companies (their most important strategy is buying a portion of stocks of independent companies in order to be a member of their board). The research is of improbable and selective type and its statistical population includes all the manufacturing companies which are members of Tehran stock exchange with following requirements:

1-The final of the financial year is on March. 2- To have a distinct institutional ownership in company with a specified manager and executive officer. 3- To have a distinct financial statements in Tehran stock exchange. 4To have a distinct board of directors in financial reports, related to the company. 5- The companies must be profitable during the financial year. 6- Not to be include as intermediaries, investing, monetary institute, holding and insurance. 7. Their trending suspicion must be in a way to have the capacity of being exchanged once in a year. 8- The corporation must be admitted in Tehran stock exchange pre 2005 and be active until 2011.

According to above mentioned circumstances and the effect of company size (control variable), the number of qualified corporations is 8 out of 435 . The data of this study has been gathered via "Rahavard Novin" software. The bibliography method is applied to collect the literature review and to determine the models.

Due to the questions and the hypothesis tests, the survey is applied the multi-variable regression with panel data arrangement using Eview8 software. Before doing of the regression we must ensure the hypothesis necessary to perform including: inexistence of collinearity, inexistence of series correlation and inexistence of co-integration and data viability.

Hence, considering the effect of dividend policy on delegation conflicts, this study investigates the relationship between the corporate governance and the institutional stock ownership with dividend in Tehran stock exchange.

The paper select eighty one active companies in stock exchange and the research process will be conducted based on the research variables and the availability of the information about companies.

The research uses the following model (godfred A. bokpin):

$\mathrm{DIV}_{\text {it }}=\delta \mathrm{INST}_{\mathrm{it}}+\lambda \mathrm{GOV}_{\mathrm{it}}+\mathrm{x} \mathrm{CONTRL}_{\mathrm{it}}+\varepsilon_{\mathrm{it}}$

Where

DIV: the dividend

INST: the institutional stock ownership

GOV: the corporate governance

CONTRL: the control variables 
I: incorporation

T: Time

Dependent variables

Dividend: it is calculated as dividend yield, i.e. dividend to stock cost at the end of the year.

Independent variables

The corporate governance: this index shows the observance of corporate governance standards by the companies. This ranking is done by different organizations in different companies, but there is not a special institution for this in Iran. Therefore, considering the Godfred A. Bokpin's model, (2011) we can conclude that corporate governance rate is computed based on 3 criteria: board size, board independency, and board duality.

GOV $\left\{\begin{array}{l}\text { Board size (number of board members) } \\ \text { Board independency (the proportion of non-executive board members) } \\ \text { Management duality (if the manager is also the chairman of the board) }\end{array}\right.$

Management duality (if the manager is also the chairman of the board)

The institutional stock ownership is each real or legal entity that purchases over 5 percent (5 billion Rials) of nominal value of securities under publication (institutional inventors - Section 27 of the Securities Market Law). Control variables

Financial leverage (the proportion of long term liability to total asset)

Firm size (assets logarithm at the end of the year)

\section{Results and Discussion}

Due to the results there is no Collinearity between the independent variables. According to the findings of the research, the null hypothesis $\left(\mathrm{H}_{0}\right)$ on cointegration will be rejected. Consequently, the model variables are cointegrated and have a long term equilibrium relationship. Hence, the regression is not a false regression.

The F-limer is significant at 5\% confidence level (as we can see at table1). It means that panel model is more suitable for the regression. Hausman test is used to elect fixed or random effects model. The results show that at $5 \%$ confidence level, the test is significant, i.e. fixed effects model is preferred to be conducted. After selecting the fixed effects model we repeated the delegation model. The results of the mode estimation are given in table2.

Table 1: The results of F-limer and Hausman test

\begin{tabular}{|c|c|c|c|}
\hline \multicolumn{4}{|c|}{ F- limer Test } \\
\hline Effects Test & Statistic & d.f. & Prob. \\
\hline Cross-section F & 5.882845 & $-80,471$ & 0.0000 \\
\hline Cross-section Chi-square & 390.711981 & 80 & 0.0000 \\
\hline Period F & 2.133137 & $-6,471$ & 0.0484 \\
\hline Period Chi-square & 15.12144 & 6 & 0.0193 \\
\hline Cross-Section/Period F & 5.713627 & $-86,471$ & 0.0000 \\
\hline Cross-Section/Period Chi-square & 403.002178 & 86 & 0.0000 \\
\hline \multicolumn{4}{|c|}{ Hausman test } \\
\hline Test Summary & Chi-Sq. Statistic & Chi-Sq. d.f. & Prob. \\
\hline Cross-section random & 12.887399 & 6 & 0.0449 \\
\hline
\end{tabular}

Table 2: The results of estimation of the model

\begin{tabular}{|c|c|c|c|c|}
\hline Variable & Coefficient & Std. Error & t-Statistic & Prob. \\
\hline C & 2967.648 & 619.6428 & 4.789288 & 0.0000 \\
\hline duality & 159.5541 & 82.08594 & 1.943745 & 0.0525 \\
\hline Board size & -256.5628 & 104.7957 & -2.448218 & 0.0147 \\
\hline Board independence & 62.22848 & 178.4813 & 0.348655 & 0.7275 \\
\hline Institutional Stock Ownership & 4.69765 & 3.275926 & 1.433991 & 0.1522 \\
\hline firm size & -167.1038 & 53.98507 & -3.095371 & 0.0021 \\
\hline financial leverage & -384.5429 & 409.9266 & -0.938078 & 0.3487 \\
\hline R-squared & 0.540513 & & \\
\hline Adjusted R-squared & 0.450762 & & \\
\hline Durbin-Watson stat & 1.769685 & & \\
\hline F-statistic & 6.022359 & & \\
\hline P-value(F-statistic) & 0.0000 & & \\
\hline
\end{tabular}

The model processing indexes show F-statistic, equal to 6.022359 , is significant at $5 \%$ confidence level. It means that the performed model is efficient. Also, Watson quantity indicates that there is no series correlation in 
the model. The coefficient of determination indicates that the model specifies a change of 45.07 percent of independent variables. After the model being confirmed, we will interpret the coefficients.

For firm size variable, $t=-3.095371$ is significant at error term of 0.05 and it means that there is a negative relationship between dividend and firm size. For financial leverage variable, $t=-0.938078$ is not significant. The effectiveness of financial leverage is probably related to financing structure of companies. In Iran this is often happened in banks and is not related to profit distribution.

$\mathrm{H}_{1}$ : for institutional ownership variable, $\mathrm{t}=1.433991$ is not significant and this means that dividend and institutional ownership are not related. Findings in this research do not accord with those of Vi Zhang (2003) from china, and Josh Kumar (2005) from India. It can be due to Iran's ownership structure that is often handled by institutions. That's why the relation between institutional ownership and dividend is not significant.

$\mathrm{H}_{2}$ : for corporate governance, considering the results of side theories, at $\mathrm{t}=1.648321$ there is a negative and significant relation between corporate governance and dividend at error term of $10 \%$. The evidences show a replacement relationship between dividend and corporate governance variable. (Companies with less corporate governance rate, pay more dividends to their shareholders). In fact, this encourages shareholders for investing in companies. Since, financial security of Iranian companies is often supplied by loans and stocks and it is vital for them to gain credit. Hence, in order to attract shareholders and investors, companies with fewer shareholder rights pay more cash dividend.

$\mathrm{H}_{2-1}$ : T-statistic, $\mathrm{t}=-2.4482218$, is significant for board size variable at $5 \%$ confidence level. This means that there is a negative significant relation between the dividend and the board size, i.e. due to the results, when the board size increases the dividend will decrease.

$\mathrm{H}_{2-2}$ : T-statistic, $\mathrm{t}=0.348655$, is not significant for the board independency. Therefore, there is no significant relation between the dividend and the board independency.

It can be image two reasons for rejecting this hypothesis: 1- The simultaneous membership of non-executive members in several boards may reduce their effectiveness. 2- The levels of experience, and education and period of management is different. Minor independence of members can be covered by executives' experience, proficiency, and knowledge on internal affairs of the company.

$\mathrm{H}_{2-3}$ : T-statistic, $\mathrm{t}=1.943745$, is significant at $10 \%$ for board duality variable. Thus, there is a weak direct relation between the dividend and the board duality.

\section{Conclusion}

The results of the paper show that companies with less corporate governance rate pay more dividends to their shareholders. In fact, more payment encourages shareholders to invest in companies. But they did not find a significant relation between the institutional ownership and the dividend. It can be due to the Iranian companies' ownership structure that is often handled by institutions and this will impress the research results. These results can be useful for those who want to involve in capital market based on a company dividend.

\section{References:}

[1] Moaradzadeh, Mahdi; Nazemi Ardakani, Mahdi; Gholami, Reza, Farzani, hojjatollah, (2009), Investigating the relationship between institutional stock ownership and earnings management at accepted companies in Tehran stock exchange, Study of Accounting and Auditing 55, 85-98

[2] Mansour Jahangiri, (2009), Commercial Code,Tehran Didar publication

[3] Islamic Republic of Iran's securities market law, passed by Islamic consultative assembly (The Parliament), (2007)

[4] Raymon kivi and luke van kempenhood, translated by abdul Hossain Nik gohar, (1385), Research methods in Social Sciences, Tootiya publication

[5] Dr. karim Mansourfar, (2006), Statistical methods, Tehran university publications

[6] Hassass Yeganeh, Yahya (2005), Concepts of corporation governance, Hessabdar Magazine 167, January

[7] Ebrahimi Kurdlor, Ali, (2007)," Corporate Governance and the role of institutional shareholders in companies", Journal of Accounting Knowledge and research, Iranian Accounting Association 8, spring, 20-25

[8] Mohammad Namazi, Ehsan Kermani, (2008)," The effect of ownership structure on the performance of accepted companies in Tehran Stock Exchange", Study of Accounting and Auditing 53, fall, 100-83

[9] Jahankhani, Ali, and, Ghorbani, Saeid (2005). Identifying and explanation of determining factors of dividend policy in accepted companies in Tehran Stock Exchange. Journal of Financial Research 20, 27-48

[10] Tehran Stock Exchange, (2006), Draft Regulations on Corporate Governance of accepted companies in Tehran Stock Exchange

[11] Tehran Stock Exchange, (2007), Operating instructions of accepted companies' disclosure policy

[12] Adaoglu Cahit. Instability in the dividend policy of the Istanbul Stock Exchange_ISE/corporations: evidence from an emerging market, Emerging Markets Review 2000; 1: 252-27

[13] Pronsit Jiraporn, yixi Ning. Dividend Policy, Shareholder Rights, and Corporate Governance, Pennsylvania State University, Available at ssrn 2006.

[14] Khalili Sourkouhi, Zeinab et al, 2013, Strategic management; concepts, benefits and process, IOSR Journals of Business and Management (IOSR-JBM) e-ISSN: 2278-487X, p-ISSN: 2319-7668

[15] Sameni Keivani. Farshad et al, 2013, "The Estimation of the Underdevelopment Degree of Different Regions- A Case Study of the Cities of Guilan Province in Iran" World Applied Sciences Journal, 22 (10): 1395-1400, 2013, ISSN 1818-4952

[16] Sameni Keivani. Farshad et al, "The Historical Lack of Capital Accumulation in Iran's Agricultural Part", 11(5) IOSR Journals of Business and Management (IOSR-JBM) e-ISSN: 2278-487X, p-ISSN: 2319-7668. Volume 10, Issue 4 (May. - Jun. 2013), PP 88-90 [17] Sameni Keivani. Farshad et al, "Advantages and Barriers of E-Banking in Iran”, Nature and Science Journal 2013;11(5) 
[18] Sameni Keivani. Farshad et al, An Investigation of the Internet Effects on Business, IOSR Journals of Business and Management (IOSR-JBM) e-ISSN: 2278-487X, p-ISSN: 2319-7668. Volume 13, Issue 6 (Sep. - Oct. 2013), PP 96-99

[19] Sameni Keivani. Farshad, (2013), The Relationship between the Government Expenditures and Revenues in the Long Run, a Case Study of Iran, IOSR Journals of Business and Management (IOSR-JBM) e-ISSN: 2278-487X, p-ISSN: 2319-7668. Volume 14, Issue 6 (Nov. - Dec. 2013), PP 83-87

[20] Selarka, Ekta (2005). "Ownership Concentration and Firm Value: A Study from Indian Corporate Sector", Emerging Markets Finance and Trade, November, 2005, Vol 41, Issue 6.

[21] Shleifer, Andrei, and Robert W. Vishny (1986). Large shareholders and corporate control, Journal of Political Economy 94, 461 488 .

[22] Kowalewski Oskar. Talavera Oleksandr. Corporate Governance and Dividend Policy in Poland, Warsaw School of Economics, Available at ssrn 2007.

[23] Jensen C Michael. Agency cost of free Cash Flow, corporate finance, and takeovers, American Economic Review1986; 76 : 2: 323 329 .

[24] Mitton Todd. Corporate governance and dividend policy in emerging markets, Emerging Markets Review 2004; 5: $409-426$.

[25] Silva Luis, Goergen Marc, Renneboog Luc. Dividend Policy and Corporate Governance. Oxford University Press 2004.

[26] Jung, Kooyul. and s. y.Kwon (2002). "Ownership structure and earnings informativeness: Evidence from Korea", The International Journal of Accounting 37, 301-325

[27] Velury, U and D, Jenkins (2006). "Institutional ownership and the quality of earnings", Journal of Business Research, 59, 10431051

[28] Kim O (1993). Disagreements among shareholders over a firm's disclosure policy, Journal of Finance, 2:747-60.

[29] P.H.Fan, Joseph. and T.J.Wong (2002). Corporate ownership structure and the informativeness of accounting earnings in East Asia", Journal of Accounting and Economics 33, 401-425 